\title{
Implementasi Fungsi Manajemen pada Kegiatan Sertifikasi Pembimbing Manasik Haji
}

\author{
Novita Irawati ${ }^{1 *} \&$ Asep Iwan Setiawan ${ }^{2}$ \\ ${ }^{12}$ Jurusan Manajemen Dakwah, UIN Sunan Gunung Djati, Bandung \\ *Email : Novita.irawati94@gmail.com
}

\begin{abstract}
ABSTRAK
Penelitian ini bertujuan untuk mengetahui bagaimana implementasi fungsi manajemen pada kegiatan sertifikasi pembimbing manasik haji angkatan ke-VII yang dilaksanakan oleh pembimbing manasik haji Jawa Barat. Metode penelitian menggunakan metode deskriptif dengan pendekatan kualitatif. Hasil penelitian menunjukan pada program Sertifikasi Bembimbing Manasik Haji di Kantor Kemeterian Agama Jawa Barat Angkatan Ke-VII di dalamnya terdapat aktivitas fungsi manajemen yaitu: perencanaan, pengorganisasian, penggerakan dan pengawasan diimplementasikan dengan bak dengan memenuhi standar operasional prosedur. Artinya setiap proses atau tahap terdapat dalam kegiatan tersebut telah dilaksanakan cukup baik. Perencanaan dilakukan dari tahap administrasi kegiatan seperti perancangan anggaran kegiatan, tempat, narasumber dan materi. Pengorganisasian yang tertata dengan baik. Keberhasilan implementasi manajemen terlihat dari terselenggaranya kegiatan dengan baik. Dari segi pengawasanpun dilakukan langsung oleh tim dari Kementerian Agama Jawa Barat.
\end{abstract}

Kata Kunci : Implementasi; Fungsi Manajemen; Sertifikasi Pembimbing Manasik Haji

\section{ABSTRACT}

This article aims to find out an implementasion of management function on the certification of the hajj pilgrims of the VII generation conducted by the hajj pilgrims of west java. The research used descriptive method with qualitative approach. The results showed on the hajj manasik guider certification program in the office of Religion Ministry West Java VII generation. There are managemen activity fungtions such as planning, organizing, mobilization and supervision that implemented well by meeting the standard procedure operational, this means that every process or stage contained in these activities has been implemented quite as well. Plans are done from the administrative stage of activities such as done from the design of activitiy budget, place, resource and material. The organizing organized well. The successful implementasion of management is seen from the implementation of the activity as well. In terms of supervision is done directedly by the team from the ministry of religious of West Java.

Keywords: Implementation; Manajement Functions; Certivication of Hajj Drivers; 


\section{PENDAHULUAN}

Perjalanan jamaah haji Indonesia perlu adanya bimbingan terlebih dahulu meliputi Bimbingan Manasik dan Perjalanan Haji, adapun proses Bimbingan Manasik Haji merupakan proses penyampaian materi dan praktik manasik haji dan umrah bagi jamaah haji yang akan berangkat ke Arab Saudi. Materi bimbingan meliputi manasik ibadah, manasik perjalanan haji, pelayanan haji, dan kesehatan serta hak dan kewajiban jamaah haji. Sertifikasi itu sendiri bermakna sebagai bagian dari proses penilaian dan pengakuan pemerintah atas kemampuan dan keterampilan seseorang untuk melaksanakan tugas sebagai pembimbing manasik secara professional. Apabila proses pembimbing dilakukan dengan materi dan metode yang tepat serta dilakukan oleh pembimbing yang bersertifikat diyakini akan melahirkan jamah haji yang mandiri (Allolagi \& Setiawan 2016:154). Bimbingan manasik ialah pelaksanaan sertifikasi pembimbing haji di lakukan untuk menjadikan pembimbing yang ’professional. Dengan menghadapi jamaah haji yang memiliki karakter yang berbeda-beda. Jamaah haji yang ditemukan tersesat dalam perjalanan. Membantu jamaah dalam membangun komunikasi dengan lingkungan ketika melaksanakan ibadah haji (Allolagi \& Setiawan, 2016:129).

Bimbingan di atas pada umumnya dilaksanakan oleh Kelompok Bimbingan Ibadah Haji (KBIH), Kelompok Bimbingan Haji adalah lembaga sosial keagamaan islam yang telah mendapatkan ijin dari Kementrian agama untuk menyelenggarakan dan melaksanakan bimbingan ibadah haji. Dalam hubungannya dengan kegiatan pembinaan kepada calon Jemaah haji, dalam hal ini pemerintah membuka diri terhadap adanya peran suatu masyarakat. Bentuk peran serta dan keterlibatan masyarakat itu, kini telah melembaga dalam bentuk oragnisasi yakni Kelompok Bimbingan Ibadah Haji $(\mathrm{KBIH})$ dan Ikatan Persaudaraan Haji Indonesia (IPHI). Kedudukan pemerintah adalah sebagai penyelenggara ibadah haji sedangkan KBIH adalah mitra kerjasama pembimbing calon jamaah haji (Prahaji dan Pascahaji). KBIH adalah penyelenggara swasta yang merupakan perpanjangan tangan dari kementrian agama sebaga pengemban UU dalam hal memberikan bimbingan manasik haji (Sukayat, 2016:75).

Pelaksanaan sertifikasi haji seringkali menemukan problematikaproblematika baik dalam problematika perjalanan maupun problematika ibadah salah satu dugaan yang muncul adalah bahwa problematika di atas datang dari petugas pembimbing haji terkait dengan kurangnya kemampuan pembimbing dalam memanage permasalahan-permasalahn jamaah. Di segi lain di duga tingkat pengetahuan dan pemahaman manasik atau ibadah haji di pandang kurang memadai dan masalah-masalah lainnya. Menyadari problematika ini kemenag mengambil kebijakan tertentu yaitu melakukan standarisasi kemampuan dan wawasan petugas pembimbing haji sesuia dengan keputusan Dirjen PHU Kemenag RI Nomor D/223/2015 Tentang Pedoman Sertifikasi Pembimbing Manasik Haji Dan Keputusan Dirjen PHU Kemenag RI Nomor D/127/2016 
Tentang Perubahan Atas Keputusan Dirjen PHU Nomor D/223/2015 Tentang Pedoman Sertifikasi Pembimbing Manasik Haji. Oleh karena itu Kantor Wilayah Kementerian Agama Provinsi Jawa Barat dalam rangka meningkatkan kualitas pembimbing manasik haji yang professional Kantor Wilayah Kementerian Agama Provinsi Jawa Barat bekerjasama dengan pemerintah provinsi Jawa Barat dan Universitas Islam Negri (UIN) Sunan Gunung Djati Bandung akan menyelenggarakan sertifikasi pembimbing manasik haji professional dengan menggunakan anggaran yang bersumber dari APBD Provinsi Jawa Barat 2016.

Melaksanakan program sertifikasi pembimbing manasik haji sudah di lakukan di beberapa tempat adapun kegiatan yang sudah dilaksanakan yaitu Angkatan Ke-1 Bertempat di Bekasi pada tanggal 28 Mei-06 Januari 2015, Angkatan Ke-2 Bertempat di Bekasi pada tanggal 07-16 Juni 2015, Angkatan Ke3 di Bekasi pada tanggal 20-28 Maret 2016, Angkatan Ke-4 di Bekasi pada tanggal 28 Maret-06 April 2016, Angkatan Ke5 di Bekasi pada tanggal 11-19 April 2016, Angkatan Ke-6 di Jakarta Pada tanggal 6-14 November 2016, dan Angkatan Ke-7 di Jatinangor pada tanggal 27 November-6 Desember 2016. Dalam pelaksanaan sertifikasi pembimbing manasik haji yang telah di lakukan sebanyak 7 kali diasumsikan terjadi dinamika atau perkembangan sertifikasi pembimbing manasik haji secara manajemen dengan demikian diperlukan penelitian lebih mendalam mengenai fungsi-fungsi manajemen.

Pelaksanaan manajemen yang baik akan mampu mengoptimalkan pemanfaatan sumber-sumber dan mengkoordinasikan tugas-tugas untuk mencapai tujuan. Keberhasilan dalam mencapai tujuan tersebut tidak bisa lepas dari empat fungsi dalam manajemen, dalam penelitian ini menggunakan teori fungsi manajemen dari G.R Terry sebagimana yang diungkapkan oleh Geoge R. Terry bahwa manajemen memiliki empat fungsi, yaitu Perencanaan (Planning), Pengorganisasian (Organizing), Penggerakan (Actuating), dan pengawasan (Controling) (Hasibuan, 2006:38).

Sebagaimana yang telah dipaparkan dalam " UU Nomor 13 Tahun 2008 tentang penyelenggaraan ibadah haji” Kantor Wilayah Kementerian Agama Jawa Barat sebagai salah satu instansi penyelenggaraan haji memiliki peran aktif dalam merencanakan dan melaksanakan program sertifikasi haji pemerintah telah melibatkan banyak pihak untuk ikut berpartisipasi sebagai mitra kerja. Tetapi pemerintah juga menyadari bahwa kapasitas pemeintah dalam merencanakan dan melaksanakan program sertifikasi haji relatif. Untuk itu partisipasi lembaga lain sangat diharapkan seperti bekerjasama dengan UIN Sunan Gunung Djati Bandung kususnya fakultas Dakwah dan Komunikasi dengan adanya kerjasma seperti itu merupakan tanggapan positif bagi kita selaku mahasiswa UIN SGD Bandung.

Dari latar belakang masalah tersebut dapat dirumuskan beberapa masalah dengan rumusan masalah: bagaimana tahapan perencanaan sertifikasi pembimbing 
manasik haji ke-VII di kantor wilayah kementerian agama jawa barat?, bagaimana pengorganisasian sertifikasi pembimbing manasik haji ke-VII di kantor wilayah kementerian agama jawa barat, bgaimana tehnik sertifikasi pembimbing manasik haji ke-VII di kantor wilayah kementerian agama jawa barat?, bagaimana proses pengawasan sertifikasi pembimbing manasik haji ke-VII di kantor wilayah kementerian agama jawa barat?

Metode yang digunakan dalam penelitian ini adalah metode deskriptif, dengan menganalisis hasil pengumpulan data melalui observasi, wawancara dan studi dokumentasi dengan panitia penyelenggara sertifikasi pembimbimbing manasik haji di kampus UIN Sunan Gunung Djati Bandung, Bandung, Jawa Barat.

\section{LANDASAN TEORITIS}

Teori yang dijadikan landasan dalam penelitian ini adalah terori Fungsi Manajemen dari G.R. Terry sebagimana yang diungkapkan oleh Geoge R. Terry bahwa manajemen memiliki empat fungsi, yaitu Perencanaan (Planning), Pengorganisasian (Organizing), Penggerakan (Actuating), dan pengawasan (Controling) (Hasibuan, 2006:38).

Perencanaan adalah memilih dan menghubungkan fakta dan membuat serta menggunakan asumsi-asumsi mengenai masa yang akan datang dengan cara menggambarkan dan merumuskan kegiatan-kegiatan yang diperlukan untuk mencapai hasil yang diinginkan (Terry; Hasibuan, 2001: 92).

Perencanaan adalah fungsi seorang manajer yang berhubungan dengan pemilihan alternatif-alternatif dari tujuan-tujuan, kebijakan-kebijakan, prosedurprosedur, dan program-program (Hasibuan, 2001: 92). Fungsi dasar manajemen, karena organizing, staffing, directing, dan controlling semua itu harus terlebih dahulu direncanakan"(Hasibuan, 2001:91).

Berdasarkan atas pendapat-pendapat di atas, jelaskan bahwa perencanaan dianggap sebagai suatu proses, dianggap sebagai suatu fungsi dan dapat dianggap sebagai suatu keputusan. Perencanaan sebagai suatu proses karena perencanaan adalah suatu tindakan pemilihan yang terbaik/menguntungkan diri dari berbagai alternatif dalam usahana pencapaian tujuan. Adapun perencanaan sebagai fungsi manajemen dimana pemimpin (manager) wajib melakaukan perencanaan sebagai pedoman dalam kegiatannya untuk mencapai tujuan organisasi. Sedangkan perencanaan sebagai keputusan ialah untuk kejelasan apa yang akan dilakukan, bilamana akan dilakukan dan siapa yang akan melakukan (Handayaningrat, 1994:126).

Tujun Perencanaan secara ringkas dapat dikatakan bahwa lebih mengarah kepada pencapaian tujuan yang efektif dan efisisen, karena dengan perencanaan dapat meminimalisir kemungkinan-kemungkinan terjadinya penyimpangan dalam pencapaian tujuan tersebut.

Pengerorganisasian merupakan kegiatan dasar dari manjemen yang 
melaksanakan untuk mengatur seluruh sumber-sumber yang dibutuhkan termasuk unsur manusia. Tujuan dari pengorganisasian adalah untuk membimbing manusiamanusia agar kerjasama secara efektif. Seorang manajer harus tahu kegiatankegiatan mana yang perlu ditangani, siapa-siapa yang membantu dan siapa-siapa yang dibantu, jallur komunikasi, liku-liku pekerjaan yang harus diikuti, keterangan antar pribadi pegawai dan antar kelompok kerja dan tugas dari kelompok kerja masing-masing (Terry 1986:73).

Menurut Sondong P. Siagian dalam bukunya Filsafat Administrasi organisai sebagai alat administrasi dan manajemen, dapat ditinjau dari dua susut pandnag. Pertama, organisasi dapat dipandang sebagi " wadah" dimana kegiatan-kegiatan adminitrasi dan manajemen dijadikan, sebagai wadah organisasi bersifat relaif statis karena tidak ada satu organisai yang berkembang, tumbuh dan maju yang berada dalam keadaan absolut statistis. Kedua : organisai dapat dipandang sebagai "proses" dimana analisis interaction antara orang-orang yang menjadi anggota oragnaisasi itu. Karenanya organisai sebagai proses jauh lebih dinamis sifatnya dibandingkan dengan organisai sebagai wadah. Organisai sebagai proses membawa kita kepada pembahasan dua macam hubungan di dalam organisai, yaitu hubungan formal yang menimbulkan formal organization dan hubungan informal yang menimbulkan informal organization. Hubungan formal antara orang-orang dalam organisasi pada umumnya yang tela diatur dalam dasar hokum pendirian organisasi dan pada struktur organisasi serta hierarki yang terdapat dalam organisasi. Sebaliknya hubungan informal antara orang-orang di dalam organisai tidak diatur dalam dasar hukum pendiri organisai (Siagian, 2003:96).

Telah dikatakan bahwa hasil pengorganisasian ialah terciptanya suatu organisasi yang dapat digerakan sebagai suatu kesatuan dalam rangka usaha pencapaian tujuan yang telah ditentukan, suatu organisai yang memiliki ciri-ciri (sifat-sifat) sebagai berikut, suatu organisai yang memiliki ciri-ciri (sifat-sifat) sebagai berikut: Terdapat tujuan yang jelas, Tujuan organisasi harus dipahami oleh setiap orang di dalam organisasi, Tujuan organisasi harus diterima oleh setiap orang dalam organisasi, Tujuan kesatuan arah (unity of direction), Adanya kesatuan perintah (unity of command), Adanya keseimbangan wewenang dan tanggung jawab seseorang, Adanya pembagian tugas (distribution of work), Struktur organisasi harus di susun sederhana mungkin, Pola dasar organisasi harus permanen, Adanya jaminan jabatan (security of tenure), Imbalan yang diberikan kepada setiap orang harus setimpal dengan jasa yang diberikan, Penempatan orang yang sesuai dengan keahliannya (the right man on the right place), (Siagian, 2003:97-99).

Actuating adalah suatu tindaka untuk mengusahakan agar semua anggota kelompok berusaha untuk mencapai sasaran yang sesuai dengan perencanaan manajerial dan usaha-usaha organisai. Sedangkan Actuatting menurut G.R Terry yaitu: Actuating is setting all members of the group to want to achieve to strike to achieve the objective willingly and keeping with the manajerial planning and organiszing efforts. Artinya: 
pengarahan adalah membuat semua anggota kelompok, agar mau bekerja sama dan bekerja secara ikhlas serta bergairah untuk mencapai tujuan sesuai dengan perencanaan dan usaha-usaha pengorganisasian (Hasibuan,2001:183).

Tujuan penggerakan secara ringkas dapat dikatakan Menciptakan kerjasama yang lebih efisien, Mengembangkan kemampuan dan keterampilan staf, Menumbuhkan rasa memiliki dan mneyukai pekerjaan, Mengusahakan suasana lingkungan kerja yang dapat menimbulkan motivasi dan prestasi kerja staf, Membuat organisai berkembang lebih dinamis.

Secara praktis fungsi Actuating ini merupakan usaha untuk menciptakan iklim kerjasnaa diantara staf pelaksana program dehingga tujuan organisai dapat tercapai secara efektif dan efisien. Fungsi actuating adalah sebagai berikut: Mengimplementasikan proses kepemimpinan, pembimbing dan pemberian motivasi kepada tenaga kerja agar dpaat bekerja secara efektif dan efisien dalam pencapaian tujuan, Memeberikan tugas dan penjelasan rutin mengenai pekerjaan, Menjelaskan kebijakan yang ditetapkan, Proses implementasi program agar dapat dijalankan oleh seluruh pihak dalam organisai serta proses memotivasi agar semua pihak tersebut dapat menjalankan tanggung jawabnya dengan penuh kesadaran dan produktifitas yang tinggi (fungsi-manajemen-actuating, Sandiego di akses pada tanggal 13 April 2017 pkl 21:02).

Berkaitan dengan bahasan tentang pengertian pengawasan tersebut, berikut ini dikemukakan beberapa teori, konsep maupun batasan serta pendapat dari para ahli dibidangnya. Menurut Samsudin mengutip dari (Kadarisman, 2012:172). Mengemukakan sebagai berikut: Pengawasan sumber daya manusia adalah kegiatan manajemen dalam mengadakan pengamatan terhadap: Pertama sumber daya manusiayang ada dalam organisasi; kedua sumber daya manusia yang benarbenar dibutuhkan organisasi; ketiga paaran sumber daya manusia yang ada dan memungkinkan; empat kualitas sumber daya manusia yang dimilliki dan yang di pasaran tenaga kerja; lima kemampuan individu dari setiap sumberdaya manusia dalam organisasi; enam upaya meningkatkan kemampuan sumberdaya manusia, dan sebagainya.

\section{HASIL DAN PEMBAHASAN}

Penelitian ini dilakukan di puri katulistiwa yang beralamat di Jl. Jatinangor Km. 20 Cibeusi. Jatinagor, Sumedang, Kabupaten Sumedang Jawa Barat 45363. Lokasi ini tempat dilaksanakannya program sertifikasi pembimbing mansik haji oleh sebab itu penulis juga ikut berpartisipasi dalam pelaksanaan sertifikasi pembimbing manasik haji.

Hasil penelitian ini menemukan tahap perencanaan sertifikasi pembimbing manasik haji, tahap pengorganisasian sertifikasi pembimbing manasik haji, tehnik pelaksanaan sertifikasi pembimbing manasik haji dna proses pelaksanaan sertifikasi pembimbing mansik haji. 


\section{Tahap Perencanaan Sertifikasi Pembimbing Manasik Haji}

Dalam sebuah manajemen yang baik, fungsi-fungsi dalam manajemen dilaksanakan dnegan baik pula. Pelaksanaan manajemen yang baik akan mampu mengoptimalkan pemanfaatan sumber-sumber dan mengkoordinasikan tugastugas untuk mencapai tujuan. Keberhasilan dalam mencapai tujuan tersebut tidak bisa lepas dari empat fungsi dalam manajemen, dalam penelitian ini menggunakan teori fungsi manajemen dari G.R Terry sebagimana yang diungkapkan oleh Geoge R. Terry bahwa manajemen memiliki empat fungsi, yaitu Perencanaan (Planning), Pengorganisasian (Organizing), Penggerakan (Actuating), dan pengawasan (Controling).

Perencanaan dilakukan dari tahap administrasi kegitan seperti perancangan anggaran kegiatan, temapat, narasumber dan materi. Oleh karena itu semua perencanaan yang ada tercatat. Akan tetapi agar lebih jelas lagi dalam tehnik perencanaan yaitu di dalamnya terdapat latar belakang pelatihan, tujuan dan target kegiatan, dasar hukum kegiatan, kondisi dan latar belakang peserta pelatihan, perencanaan pembentukan materi sertifikasi, serta perencanaan nara sumber. Bukan hanya itu saja dalam hal perencanaan pihak panitia dari UIN SGD Bandung dan Kanwil Kementerian Provinsi Jawa Barat melakukan rapat yang membahas mengenai penentuan narasumber, penentuan tentang moderator dan penentuan hari serta tempat pelaksanaan. Selanjutnya juga dilakukan evaluasi pada kegiatan yang dilakukan pada angkatan yang sebelumnya. Setelah rapat perdana selseai selanjutnya ada rapat kedua yaitu akan berkumpul dengan narasumber untuk menyamakan presepsi materi yang akan di berikan oleh oleh peserta dan evaluasi dari kegiatan sebelumnya. Jadi dalam fase perencanaan itu pertama dimulai dari rapat persiapan duakali kemudian rapat penentuan narasumber waktu dan tempat kemudian rapat untuk waktu seleksi dan hasil seleksi, rapat pemantapan kegiatan final biasanya itu dihadiri assessor, panitia dari kanwil maupun UIN di tambah dengan Assessor.

Latar belakang pelatihan sertifikasi pembimbing manasik haji yaitu: terselenggaranya program pemerintah untuk mewujudkan sumber daya manusia yang berkualiatas (professional dan amanah) dalam meningkatkan mutu penyelenggaraan ibadah haji di Indonesia merupakan sesuatu yang relevan san barwawasan ke deapan. Relevan karena ia sejiwa dengan visi-misi Kementerian Agama dibidang penyelenggaraan ibadah haji. Kemudian berwawasan ke depan. Mengingat peran kementerian Agama yang terus menguat dalam proses pembangunan nasional.

Diantara upaya strategis yang ditempuh Kementerian Agama dalam mewujudkan niat diatas adalah penyelenggaraan kegiatan Pelatihan sekaligus Sertifikasi Pembimbing Manasik Haji. Alasan utama dari penyelenggaraan kegiatan ini karena para pembimbing haji merupakan salah satu elemen pokok dalam meningkatkan mutu penyelenggaraan ibadah haji. Para pembimbing haji memiliki 
peranan penting dalam meningkatkan wawasan, kemampuan dan keterampilan jamaah haji dalam memahami dan melaksanakan seluruh rangkaian ibadah haji yang dijalaninnya. Mellaui kegiatan sertifikais ini para pembimbing haji akan dipertajam peranannya sebagai ujung tombak dalam melakukan pembinanaan, pelayanan dan perlindungan bagi para jama'ah haji (Rahmat Allolangi \& Setiawan, 2016:65).

Selain itu kegiatan sertifikais pembimbing manasik haji ini juga dilakukan dalam rangka menyamakan persepsi di kalangan para pembimbing haji mengenai seluruh tahapan proses bimbinga ibadah haji. Hal ini amat penting mengingat masih beragamnya pemahaman tentang proses bimbingan ibadah haji di kalangan para pembimbing haji Indonesia. Dengan demikian, kegiatan pelatihan dan sertifikasi pembimbing manasik haji disamping dapat berfungsi sebagai sarana pembekalan yang efektif bagi peningkatan wawasan, keterampilan dan integritas para pembimbing haji, ia juga dapat menjadi wahana yang menengahi berbagai perbedaan pemahaman dalam proses bimbingan haji di kalangan pera pembimbing haji.

Dengan bekal kompetensi (profesionalisme) dan pemahaman yang memadai tentang kebijakan penyelenggaraan ibadah haji, pada akhirnya para pembimbing haji kaan mampu mmeberikan proses pembimbingan yang bermutu dalam bentuk pembinaan, pelayanan, dan perlindungan yang sebaik-baiknya kepada para jama'ah haji yang merupakan inti dari penyelenggaraan ibadah haji. Sehingga para jama'ah haji benar-benar dapat menunaikan ibadah hajinya sesuai dengan tuntutan ajaran agama islam dan mampu menjadi jamaah haji yang mandiri dalam mengatasi berbagai persoalan yang dihadapinya (Allolangi \& Setiawan, 2016:66).

Profesionalisme para pembimbing manasik haji di atas tertentu tidak akan terwujud secara optimal tanpa adanya dukungan, koordinasi, intergrasi, sinkronisasi, dan kerjasama seluruh elemen yang terkait dengan penyelenggaraan ibadah haji di Indonesia. Karena itu, Kementerian Agama Provinsi Jawa Barat bekerjasama dengan UIN Sunan Gunung Djati Bandung serta Pemerintah Provinsi Jawa Barat bermaksud turut aktif menyukseskan agenda kementerian agama dalam meningkatkan mutu penyelenggaraan ibadah haji di Indonesia melalui penyelenggaraan kegiatan Sertifikasi Pembimbing Manasik Haji (Allolangi \& Setiawan, 2016:67).

Dalam pelaksanaannya seringkali menemukan problematika-problematika baik dalam problematika perjalanan maupun problematika ibadah salah satu dugaan yang muncul adalah bahwa problematika di atas datang dari petugas pembimbing haji terkait dengan kurangnya kemampuan pembimbing dalam memanage permasalahan-permasalahn jamaah. Di segi lain di duga tingkat pengetahuan dan pemahaman manasik atau ibadah haji di pandang kurang memadai dan masalah-masalah lainnya. Menyadari problematika ini kemenag 
mengambil kebijakan tertentu yaitu melakukan standarisasi kemampuan dan wawasan petugas pembimbing haji sesuai dengan keputusan Dirjen PHU Kemenag RI Nomor D/223/2015 Tentang Pedoman Sertifikasi Pembimbing Manasik Haji Dan Keputusan Dirjen PHU Kemenag RI Nomor D/127/2016 Tentang Perubahan Atas Keputusan Dirjen PHU Nomor D/223/2015 Tentang Pedoman Sertifikasi Pembimbing Manasik Haji. Oleh karena itu Kantor Wilayah Kementerian Agama Provinsi Jawa Barat dalam rangka meningkatkan kualitas pembimbing manasik haji yang professional Kantor Wilayah Kementerian Agama Provinsi Jawa Barat bekerjasama dengan pemerintah provinsi Jawa Barat dan Universitas Islam Negri (UIN) Sunan Gunung Djati Bandung akan menyelenggarakan sertifikasi pembimbing manasik haji professional dengan menggunakan anggaran yang bersumber dari APBD Provinsi Jawa Barat 2016.

Tujuan kegiatan: pertama; Meningkatkan kualitas, kreativitas, dan integritas pembimbing manasik haji agar mampu melakukan aktualisai potensi diri dan tugasnya secara professional guna mewujudkan Jemaah haji yang mandiri dalam ibadah dan perjalanan, kedua; Memberikan pengakuan dan perlindungan atas profesionalitas pembimbing manasik haji dalam melaksanakan tugas, tanggung jawaban kewenangannya dalam memberikan bimbingan manasik haji sesuai ketentuan pemerintah, ketiga; Menstandarisasikan kompetensi pembimbing manasik haji agar dapat memberikan jaminan kualitas pelayanan di bidang bimbingan manasik haji, keempat; Menjadi mediasi bagi Direktorat Jenderal Penyelenggaraan Haji dan Umrah dalam mewujudkan penjaminan mutu (quality assurance) bagi pembimbing manasik haji, baik yang ada di pemerintah maupun masyarakat.

Dasar hukum sertifikasi pembimbing manasik haji: Undang-undang Republik Indonesia Nomor 13 Tahun 2008 tentang Penyelenggaraan Ibadah Haji yang telah diubah dengan Undang-undang Republik Indonesia Nomor 34 Tahun 2009 tentang Penyelenggaraan Ibadah Haji; Undang-Undang Nomor 13 Tahun 2012 tentang Penyelenggaraan Ibadah Haji; Peraturan Pemerintah Nomor 79 Tahun 2012 tentang Pelaksanaan Undang-undang Nomor 13 Tahun 2008 tentang Penyelenggaraan Ibadah Haji; Peraturan Menteri Agama Nomor 14 Tahun 2012 tentang Penyelenggaraan Haji Reguler; Keputusan Menteri Agama Nomor 396 Tahun 2003 tentang Perubahan atas Keputusan Menteri Agama Nomor 371 Tahun 2002 tentang Penyelenggaraan Ibadah Haji dan Umroh; Keputusan Dirjen PHU Kemenag RI Nomor D/54 Tahun 2010 tentang Visi Misi Direktorat Jenderal Penyelenggaraan Haji dan Umrah; Keputusan Dirjen PHU Kemenag RI Nomor D/55 Tahun 2010 tentang Rencana Strategis Direktorat Jenderal Penyelenggaraan Haji dan Umrah Tahun 2010-2014; Keputusan Dirjen PHU Kemenag RI Nomor D/239 Tahun 2010 tentang Strategi Pencitraan Penyelenggaraan Ibadah Haji; Keputusan Dirjen PHU Kemenag RI Nomor D/223/2015 tentang Pedoman Sertifikasi Pembimbing Manasik Haji (Laporan 
Penguatan Haji Pemda, 2016:7.

Selain persyartan yang harus di rencanakan dalam kegiatan sertifikasi, materipun harus di rencanakan karena para pembimbing manasik haji memiliki peranan penting dalma meningkatkan wawasan, kemampuan, dan keterampilan jama'ah haji dalam memahami dan melaksankan seluruh rangkaian ibadah haji. Karena itu, para pembimbing manasik haji wajib menguasai pengetahuan dan keterampilan mengenai beragam hal yang terkait dengan penyelenggaraan ibadah haji. Dalam kaitan ini, setiap pembimbing manasik haji memiliki tugas dan tanggung jawab untuk membantu para jamaah haji dalam melakukan setiap tahapan proses ibadah haji.

Para pembimbing manasik haji harus mampu memeberikan bimbingan manasik haji yang bermutu dalam bentuk pembinaan, pelayanan, dan perlindungan yang sebaik-baiknya kepada para jama'ah haji. Sehingga para jama'ah haji benar-benar dapat dapat menunaikan ibadah haji sesuai dengan tuntunan ajaran islam dan mampu menjadi jama'ah haji yang mandiri dalam mengatasi berbagai persoalan yang dihadapinya.

Dalam menentukan narasumber tentunya ada persyartaan yang harus terpenuhi adapun syarat untuk menjadi narasumber yaitu: pertama: narasumber sertifikasi adalah tenaga ahli yang memiliki kometensi keilmuan dan praktik; kedua: narasumeber sebgaimna dimaksud pada poin 1 harus memenuhi persyartan: Tenaga akademik pangkat minimal lector atau pendidikan s2 bidang ilmu agama islam, Pejabat/pegawai Kementerian Agama, pangkat minimal Pembina (IV/a) baik pusat maupun daerah, Menguasai materi dan pengalaman manasik serta bidang tertentu sesuai materi yang diampu, dan Menguasai metode dan pendekatan cara belajar orang dewasa; ketiga: Asesor adalah tengaa ahli yang memiliki kompetensi dalam melkaukan verifikasi persyaratan peserta sertifikasi dan penilaian sebagai dasar menentukan kelulusan peserta pembimbing manasik, Asesor sebgaaimana dimaksud pada poin 3 harus memenuhi persyaratan; Dosen aktif pada Perguruan Tinggi Agama Islam Negeri (PTAIN), Pejabat terkait, khususnya pada bidang penyelenggaraan Haji dan Umrah Kanwil Kementerian Agama Provinsi, Pendidikan minimal S2/Memiliki gelar Magister, Memiliki pengetahuan yang memadai di bidang perhajian, Memiliki kompetensi yang memadai dalam pendampingan, kebahasaan, dan pengetahuan teknis perhajian, dan Pembentukannya dilakasankan di masing-masing provinsi dengan prosedur sesuai ketentuan.

\section{Tahap Pengorganisasian Sertifikasi Pembimbing Manasik Haji}

Bukan hanya dari segi perencanaan saja yang telah di lakukan dengan matang akan tetapi dari segi pengorganisasian juga di lakukan dengan matang dengan memebentuk struktur panitia sehingga bisa saling melaksakan tugas nya dengan baik, akan tetapi tidak hanya struktur panitia saja yang diperlukan dalam kegiatan 
sertifikasi haji ini struktur organisasi kelas juga di perlukan karena untuk membantu kelancaran PBM di kelas.

Untuk memperlancar pelaksanaan program sertifikasi haji perlu di bentuk struktur panitia. Adapun struktur panitia pada kegiatan sertifikasi haji. Hal ini di jelaskan oleh bapak H. Asep Iwan Setiawan., M.Ag (wawancara, 28 April 2017) yang menyatakan sebagai berikut: "Untuk Ketua Pelaksna Dari Fakultas Dakwah yaitu Dr. Ahmad Sarbini M.Ag yang dibawahnya itu ada panitia pelaksana seperti bagian Administratif, persuratan, Akademik, dst itu sudah di bagi tugasnya untuk memantau jalannya kegiatan tersebut di tambah dengan assessor yang berperan untuk memantau jalannya kegiatan sertifikasi untuk memastikan pengetahuan dari peserta sertifikasi kemudian di pastikan bahwa sertifikasi ini memang layak menjadi peserta ataupun lulus menjadi pembimbing yang professional. Ada juga panitia dari kementerian agama yang di dalam nya dari Provinsi Jawa Barat dan ketua panitianya misalkan Dedi Iskandar dan ini sudah ada pembagian tugas nya dan jelas sehingga ketika pelaksanaan yang dari UIN itu berkaitan mengenai masalah akademik dan yang dari Kanwil kemterian agama itu nanti di tekhnis pendaftarannya kemudian untuk provinsi itu di bagian pendanaannya".

Bukan hanya struktur panitia saja yang penting dalam kegiatan sertifikasi haji ini kepengurusan/organisasi peserta sertifikasi juga perku di bentuk demi memperlancar pelaksnaan program, adapun struktur kepengurusan /organisasi pesserta sertifikasi pembimbing manasik haji yang terdiri: ketua kelas, sekertaris kelas, dan bendahara dengan ketentuan sebagai berikut: pertama; Tugas ketua kelas: ketua kelas bertugas membantu kelancaran pelaksanaan PBM di dalam kelas; Bertugas mengkoordinir kegiatan peserta di luar kelas, yaitu: Menjaga ketertiban, keamanan, kebersihan, dan ketenangan selama di asrama; menggerakan dan megarahkan penghuni asrama untuk shalat berjamaan; mengatur petugas kuliah subuh, muadzin, khatib/imam shlat jum'at; membantu kelancaran pelaksanaan kegitab olag raga, dan kegiatan lainnya di luar kelas. Kedua; Perangkat kelas mewakili peserta dalam kegiatan yang berkaitan dengan pelaksanaan sertifikasi dan bertanggung jawab atas ketertiban kelas, seperti: Menyiapkan sarana belajar dan mengajar; Menjaga ketertiban, kebersihan, dan keamnan kelas; melaporkan dan menyampaikan peserta untuk mengikuti perkuliahan secara bergiliran; endistribusikan daftar hadir pada kegiatan kelas. Ketiga; Perangkat kelas mewakili seluruh peserta dalam hal yang behubungan dengan kegiatan ko-kurikuler sebagai pendukung sertifikasi pembmbing manasik haji, seperti: menjaga kebersihan, ketertiban, dan keamanan asrama; menggerakan penghuni asrama untuk shlat berjamaah; megantar petugas kuliah subuh, imam, muadzin, dan khotib shlat jum'at; mengatur kegiatan olahraga dankegiatan lainnya diluar perkuliahan; mengawasi dan mencatat peserta yang akan meninggalkan asrama secara terkoordininatif dengan panitia. 


\section{Teknik Pelaksanaan Sertifikasi Pembimbing Manasik Haji}

Pada program Sertifikasi Pembimbing Manasik Haji Di Kantor Kementerian Agama Provinsi Jawa Barat Angkatan Ke-VII. Dalam implemetasi di lapangan pada proses pedidikan dan pelatihan telah menggunakan teori manajemen G.R Terry dan diImplentasikan sesuai dengan standar operasional prosedur yang telah ditetapkan. Hal ini di dukung dengan adanya standar operasional kerja yang menjadi acuan kegiatan, yang tertuang dalam rencana kerja operasional kegiatan sertifikasi haji. Selain itu pula dibuatkan buku yang isi dari buku tersebut ialah rangkuman berbagai hal yang memuat kegiatan sertifikasi pembimbing manasik haji. Diantaranya memuat latar belakang, dasar hukum, tujuan, ringkasan materi, target pembelajaran, narasumber, assessor dan panitia, serta dilengkapi dengan jadwal kegitaan yang telah ditetapkan oleh panitia.

Dalam tehnik pelaksanaan nya, Kegiatan penguatan petugas haji melalui sertifikasi pembimbing haji dilaksanakan selama 10 (sepuluh) hari, 27 November s.d. 6 Desember 2016 bertempat di Hotel Puri Khatulistiwa, Jalan Raya Jatinangor Km. 20, Cibeusi, Jatinangor, Cibeusi, Sumedang, Kabupaten Sumedang, Jawa Barat 45363. Kegiatan penguatan petugas haji melalui sertifikasi pembimbing haji Jawa Barat diikuti oleh 50 orang peserta yang telah dinyatakan lulus seleksi. 50 orang peserta ini terdiri atas utusan KBIH di Wilayah Provinsi Jawa Barat, Kemenag Kabupaten/Kota di Wilayah Provinsi Jawa Barat, MUI, Ormas Islam, Yayasan, Pesantren, dan PTKIN di Wilayah Provinsi Jawa Barat, dan masyarakat umum yang memenuhi ketentuan Pedoman Sertifikasi Pembimbing Manasik Haji Kemenag RI.

Sebelum dilaksanakan kegiatan penguatan petugas haji melalui sertifikasi pembimbing haji Jawa Barat, dilakukan proses pendaftaran dan seleksi calon peserta. Pendaftaran dilakukan secara online pada www.sertifikasihajijabar.info dari tanggal 15 s.d. 22 November 2016. Sementara proses seleksi meliputi seleksi administrasi, test tertulis, dan wawancara. Seleksi pokok administrasi terutama meliputi jenjang pendidikan minimal S1, pernah berhaji, pernah menjadi pembimbing ibadah haji, dan usia minimal 30 tahun maksimal 56 tahun. Test wawancara meliputi: kemampuan/keterampilan membaca dan menulis Alqur'an, wawasan tentang fiqh dan peraturan perundang-undangan haji, dan etika/akhlak pembimbing haji. Test tertulis meliputi: peraturan perundangan haji, fiqh haji, budaya Arab, wawasan tentang tugas pokok, fungsi, dan peran pembimbing haji, bahasa Arab dan bahasa Inggris. Adapun pengumuman hasil seleksi calon peserta dilakukan pada tanggal 24 November 2016 pada website http://jabar.kemenag.go.id.

Test wawancara dilaksanakan selama satu hari, tanggal 23 November 2016 bertempat di lt. 2 Ruang Seminar Gedung Pusdai Jawa Barat Jl. Dipenegoro no. 63 Kota Bandung. Sementara test tertulis dilaksanakan pada tanggal 26 November 2016 bertempat di Hotel Puri Khatulistiwa, Jalan Raya Jatinangor Km. 20, Cibeusi, 
Jatinangor, Cibeusi, Sumedang, Kabupaten Sumedang, Jawa Barat 45363. Bentuk dan metode kegiatan penguatan petugas haji melalui sertifikasi pembimbing haji Jawa Barat dilakukan melalui: Pre Test, Ceramah, Dialog, Brainstorming, diskusi, simulasi, demonstrasi, problem solving, role playing, dinamika kelompok, pemutaran film, praktik manasik haji, micro-guidin, evaluasi dan refleksi (mubasabah), post test, dan wawancara akhir.

Narasumber kegiatan penguatan petugas haji melalui sertifikasi pembimbing haji Jawa Barat adalah unsur Kementerian Agama RI, unsur Kementerian Kesehatan RI, unsur Kementerian Agama Provinsi Jawa Barat, unsur Pemerintah Provinsi Jawa Barat, dan unsur ulama dan akademisi PTAIN di Jawa Barat. Sementara kualifikasi narasumber: Guru Besar 10 orang (35\%), Doktor 11 orang (37\%), Pejabat Kemenag/pemprov. Jabar, Pakar dan Praktisi Haji 8 orang (28\%). Sementara asessor kegiatan penguatan petugas haji melalui sertifikasi pembimbing haji Jawa Barat sebanyak 10 orang, berasal Pemerintah Provinsi Jawa Barat, Kementerian Agama Provinsi Jawa Barat, dan UIN Sunan Gunung Djati Bandung (Laporan Penguatan Haji Pemda, 2016: 89-90).

Capaian OutPut Kegiatan: pertama; Kehadiran narasumber mencapai 96\%, yakni dari 30 narasumber 29 orang hadir dan 1 orang berhalangan hadir karena sakit, yakni Dr. dr. H. Eka Jusuf Singka, M.Sc., materi tentang Kesehatan Haji, kedua; 96\% narasumber memberikan langsung hard copy materi kepada panitia dan didistribusikan kepada semua peserta sertifikasi. Sebanyak 4\% narasumber memberikan hard copy materi hasil transkrip panitia, ketiga; Dari jumlah 50 orang peserta, sebanyak 48 (96\%) orang peserta mengikuti kegiatan full selama 10 hari dan 2 0rang (4\%) mengikuti selama 8 hari dikarenakan ada musibah keluarga (orang tuanya meninggal dunia), keempat; Semua peserta sangat antusias mengikuti kegiatan penguatan petugas haji melalui sertifikasi pembimbing haji, kelima; Tingkat kedisiplinan peserta dalam kehadiran di kelas pada setiap sesinya sangat tinggi, hal ini antara lain terlihat dari kehadiran rata-rata peserta datang awal waktu, bahkan beberapa peserta diantaranya ada yang 10 - 15 menit sebelum sesi dimulai mereka sudah siap di kelas, keenam; Demikian halnya dengan kinerja para asessor, semua asessor melaksanakan tugas sesuai tugas pokok, peran, fungsi, dan kewenangannya. Para asessor melaksanakan tugas secara terjadwal yang didesain sedemikian rupa dibawah koordinasi koordinator asessor. Dalam melakukan assesment terhadap perkembangan prestasi peserta termasuk dalam memberikan rekomendasi kelulusan perserta, semua asessor melaksanakan tugas secara independen, objektif, dan profesional (Laporan Penguatan Haji Pemda, 2016:9092).

Capaian out-come peserta penguatan petugas haji melalui kegiatan sertifikasi pembimbing haji dapat dilihat dari kompetensi para peserta setelah mengikuti kegiatan penguatan petugas haji melalui kegiatan sertifikasi pembimbing haji. Kompetensi peserta ini terutama meliputi penguasaan teori dan 
keterampilan/pengalaman ikhwal perhajian, serta akhlak/etika sebagai petugas/pembimbing haji. Dari tiga aspek utama kompetensi peserta tersebut dapat digambarkan indikasi-indikasi sebagai berikut: pertama; Wawasan pengetahuan para peserta tentang teori-teori perhajian dan manajemen pembimbingan ibadah haji, termasuk penguasaan peraturan perundang-undangan haji mengalami peningkatan yang signifikan, kedua; Keterampilan dan pengamalan peserta dalam mempraktikan fikih haji dan manajemen pengelolaan proses pembimbingan ibadah haji mengalami peningkatan yang signifikan, ketiga; Aspek afeksi dan refleksi para peserta yang merupakan bagian pokok dari etika/akhlak pembimbing haji mengalami peningkatan yang signifikan. Hal ini antara lain ditunjukan dalam bentuk kesantunan dalam berkomunikasi, ketawadhuan dalam bersikap, komitmen dan tanggung jawab yang tinggi sebagai petugas/pembimbing haji, dan kebanggaan dan keikhlasan sebagai petugas/pembimbing haji (Laporan Penguatan Haji Pemda, 2016:92-93).

\section{Proses Pengawasan Sertifikasi Pembimbing Manasik Haji}

Dalam kegiatan sertifikasi pembimbing manasik haji perlu ada nya pengawasan hal ini berkaitan untuk mencapai kualitas pembimbing manasik haji yang professional dan berkompeten dalam bidangnya di lakukan langsung oleh Kantor Wilayah Kementerian Agama Jawa Barat yang dapat dilihat dari keberhasilan atau terpenuhinya target atau sasaran yang telah ditentukan oleh Kantor Wilayah Kementerian Agama Jawa Barat dari kegiatan-kegiatan sebelumnya. Bentuk keberhasilan Kanwil dalam melakukan pengawasan yaitu dengan selalu suksesnya kegitan Sertifikasi haji dan antusiasnya masyarakat dalam mengikuti tes seleksi calon peserta sertifikasi.

Proses pengawasan pada sertifikasi pembimbing mansik haji. Pengawasan yang dilakukan pada sertifikasi pembimbing mnasik haji meliputi evaluasi terhadap peserta, penyelenggara, dan narasumber. Peserta, Aspek-aspek yang dinilai terhadap peserta: pertama; Tugas Resume, Resume merupakan kegiatan untuk menyelesaikan tugas dengan menuliskan pokok-pokok penting materi dalam setiap pembelajaran pada kegiatan sertifikasi. Adapun indikator penilaian sebagai berikut: Tugas ditulis tangan pada kertas yang sudah disediakan oleh panitia, Menyusun ide-ide penting dari materi sertifikasi, Menuliskan pokok-pokok pikiran dalam materi, Membuat peta konsep secara logis dan sistematis, Memberikan ide, gagasan dan komentar poko-pokok pikiran dan konsep-konsep penting materi sertifikasi. Kedua; Sikap dan prilaku, dalam aspek ini yang dinilai meliputi disiplin, kepemimpinan, kerjasama, dan prakarsa. Indicator yang dinilai masing-masing unsur sikap dan prilaku adalah sebagai berikut: Pertama, Disiplin "Disiplin adalah ketaatan dan kepatuhan peserta terhadap seluruh ketentuan yang ditetapkan oleh penyelenggara. Indicator disiplin terdiri atas: kehadiran, ketepatan hadir di kelas, ketepatan menyelesaikan tugas, etika dan sopan santun, kerapihan berpakaian, keikutsertaan dalam olah raga pagi, shlat berjamaah, dan kuliah subuh, dan 
ketentuan lain yang ditetapkan penyelenggara", Kedua, Kepemipinan "Kepemimpinan yaitu kemampuan memeberi motivasi dan menggerakan peserta lainnya, meyakinkan pendapat kepada orang lain, mempertemukan pendapat, dan mengatasi ketegangan yang mungkin terjadi" Indikator kepemimpinan anatara lain: obyektif dan tegas dalam mengambil keputusan, memebela kepentingan bersama sesuai dengan ketentuan yang berlaku, beratnggung jawab, memberikan contoh yang dapat menjadi teladan seprti komunikatif, konsisten, adil, jujur, tekun, tegas, dan rasional. Ketiga; Kerjasama, kerjasama adalah kemampuan untuk menyelesiakan tugas secara bersama-sama. Indikator kersama antara lain: menyelesaikan tugas bersama dengan orang lain secara kooperatif, membina keutuhan dan kekompakan kelompok, tidak mendikte atau mendominasi kelompok, dan mau menerima pendapat orang lain. Keempat; Prakarsa, Prakarsa merupakan kemampuan untuk menunjukan gagasan yang bermanfaat bagi kepentingan kelompk atau kepentingan yang lebih luas. Indikator prakarsa antar lain: berprilaku positif untuk membantu kelancaran sertifikasi dan membuat situasi sertifikasi lebih dinamis; mampu membuat saran-saran yang nyata; baik yang menyangkut materi sertifikasi maupun yang menyangkut kelancaran sertifikasi; dapat menyampaikan gagasan/ide baru yang kritis, konstruktif dan bermanfaat; mengajukan pertanyaan-pertanyaan yang relevan dan tiak bersifat menguji atau memojokkan orang lai; mampu mengendalikan diri, waktu, situasi dan lingkungan (Allolangi \& Setiawan 2016: 132-135).

Pelaksanaan Ujian: pertama; Ujian/test tertulis dilakukan dalam bentuk pilihan ganda dan essay, dengan ketentuan: Soal test tertulis dibuat oleh tim pelaksana sertifikasi, Pelaksanaan dan pengawasan test tertulis dilakukan oleh tim penyelenggara sertifikasi, Koreksi jawaban soal test tertulis dilakukan oleh penyelenggara sertifikasi. Kedua; Test lisan/wawancara dilakukan oleh Asessor, dengan ketentuan materi test lisan meliputi: Materi dasar, Materi inti, Materi penunjang, termasuk ujian micro guiding. Ketiga; Penilaian dan kelulusan, Kegiatan akhir sertifikais, dilakukan penilaian keluluasan dengan ketentuan: Tidak mengikuti proses pembelajaran lebih dari $8 \mathrm{JPL}$, format penilaian menggunakan bobot pre test $15 \%$, partisipasi $25 \%$, post test $20 \%$, dan micro guiding $40 \%$, standar kualifikasi kelulusan rata-rata nilai tertimbang 70-100. (Allolangi \& Setiawan 2016: 135-138).

Narasumber: pertama; Aspek yang dinilai dari penampilan narasumber antara lain: Penguasaan materi, Sistematika penyajian, Kemampuan menyajikan, Ketepatan waktu, Penggunaan metode dan sarana sertifikasi, Sikap dan prilaku; Cara menjawab pertanyaan dari peserta; Penggunaan bahasa, Pemberian motivasi kepada peserta, Pencapaian tujuan intruksional dan Kerapihan berpakaian. Penilaian terhadap narasumber dilakukan oleh peserta dan penyelenggara sertifikasi. Hasilnya diolah dan disampaikan oleh penyelenggara kepada narasumber yang bersangkutan sebagai bahan masukan untuk peningkatan 
kinerjanya pada masa yang akan datang. Kedua; Penyelenggara, Aspek yang dinilai dari panitia penyelenggara anatara lain: Evektifitas penyelenggaraan, Ketersediaan bahan sertifikasi, Kesiapan sarana dan prasarana sertifikasi, Kesesuaian antara pelaksanaan program dengan rencana, Kebersihan kelas, asrama, kafetarian, kamar mandi, WC, dan lain-lain, Ketersediaan fasilitas olah raga dan kesehatan (Allolangi \& Setiawan, 2016:138-139).

Bukan hanya dari segi pengawasan saja yang baik tetapi penyediaan sarana dan prasarana yang memadai seperti adanya proyektor dan laptop yang selalu standby untuk membantu jalannya pembelajaran. Dengan adanya sarana dan prasarana yang lengkap tentu juga sangat menunjang keberlangsungan kegitaan sertifikasi haji. Oleh sebab itu adanya keterkaitan dari mulai perencanaan sampai kepda fungsi pengawasan tentu semua itu membuat kegiatan yang dilakukan berjalan dengan baik dan selalu sukses.

Pendisiplinan peserta dilakukan absensi secara ketat dengan mengggunakan absen kode barcode secara online absensi ini dilakukan untuk membantu peserta agar datang tepat waktu dan penilaian yang di lakukan oleh panitia agar tepat dan tidak salah sasaran. Selain itu kehadiran peserta pada setiap sesinya dapat dipantau secara online oleh pihak assessor.

\section{PENUTUP}

Dalam meningkatkan profesionalisme Pembimbing Manasik Haji, seluruh aspek pengelolaannya untuk meningkatkan mutu penyelenggaraan ibadah haji di Indonesia merupakan sesuatu yang relevan dan berwawasan kedepan. Diantara upaya strategis yang ditempuh Kementerian Agama dalam mewujudkan niat di atas adalah menyelenggarakan kegiatan pelatihan sekaligus memberikan sertifikasi. Alasan utama dari penyelenggaraan kegiatan ini karena para pembimbing haji merupakan salah satu elemen pokok dalam meningkatkan mutu penyelenggara ibadah haji.

Dari sekian banyak pembahasan yang telah di paparkan, dapat di Tarik kesimpulan sebagai berikut: pertama; Dalam melaksanakan tahap perencanaan sertifikasi adanya koordinasi dengan berbagai pihak yang terkait setelah itu adanya rapat panitia dari UIN SGD Bandung dan Kanwil Kementerian provinsi Jawa Baarat dalam rapat perdana ini dilakukan mengenai; penentuan narasumber, penentuan tentang moderator dan penentuan hari serta tempat pelaksanaan. Selanjutnya juga dilakukan evaluasi pada kegiatan yang dilakukan pada angkatan yang sebelumnya. Jadi dalam fase perencanaan itu pertama dimulai dari kegiatan pertama kita mulai dari rapat persiapan 2 kali kemudian rapat penentuan narasumber dengan penentuan narasumber waktu dan tempat kemudian rapat untuk waktu seleksi dan hasil seleksi, rapat pemantapan kegiatan final biasanya itu di hadiri assessor, panitia dari Kanwil maupun UIN di tambah dengan Assesor. Kedua; Dalam melaksanakan proses pengawasan sertifikasi haji Kantor Wilayah 
Kementerian Agama Jawa Barat memiliki faktor penunjang yang baik dengan berkembangnya media elektronik seperti media cetak, computer, HP, dan media elektronik lainnya sangat membantu dalam proses pengawasan untuk berjalan dengan efektif dan efisien.

Untuk mengoptimalkan pelaksanaan kegitan sertifikasi pembimbing mansik haji dalam meningkatkan kualiatas sumberdaya manusia yang diberikan kepada para pembimbing manasik haji, maka penulis memberikan sedikit saran dan masukan kepada semua pihak yang bersangkutan baik pada instansi atau panitia serta kepada kawan-kawan yang akan menyelesaikan tugas akhir sebagai masukan yang mungkin bisa dipertimbangkan, diantaranya: Pertama; Pengelolaan pengawasan secara professional akan dapat meningkatkan kepercayaan masyarakat kepada lembaga yang menaungi penyelenggara sertifikasi haji. Kedua; Penelitian ini belum Komprehensif, karena hanya melihat dari sisi perencanaan, pengorganisasian, pelaksanaan dan pengawasannya saja, bagi yang berminat untuk meneliti tentang hal serupa, perencanaan, pengorganisasian, pelaksanaan dan pengawasan bukanlah satu-satunya hal yang bisa diteliti dalam pembuatan tugasa akhir melainkan masih banyak yang masih bisa di ungkapkan dalam penyelesaianpenyelsaian tugas akhir.

\section{DAFTAR PUSTAKA}

Allolangi, Y.R. \& Setiawan, A. I. (2016). Efektifitas Manajemen Pendidikan Dan Pelatihan Dalam Program Sertifikasi Pembimbing Manasik Haji. Bandung: Tidak di publikasikan, penelitian lembaga penelitian dan pengabdian kepada masyarakat UIN Sunan Gunung Djati Bandung

Hasibuan, M.S.P. (2006). Manajemen: Dasar, Pengantar dan Masalah. Jakarta: PT Bumi Aksara

Kadarisman, M. (2012). Manajemen Pengembangan Sumberdaya Manusi. Depok: PT Raja Grafindo Persada

Setiawan, A.I. (2014). Pengawasan, Pengendalian dan Evaluasi Dalam organisasi Ilmu Dakwah: Academic journal for Homiletic Studies, 110-135.

Setiawan, A.I. (2015). Budaya Organisasi Dalam Lembaga Islam Ilmu Dakwah: Academic journal for Homiletic Studies, 78-80.

Setiawan, A.I, (2015). Efektifitas Dakwah Fi'ah Studi Model Dakwah pada Lembaga Kampus Ilmu Dakwah: Academic journal for Homiletic Studies, 65-70.

Siagian, S.P. (2003). Filsafat Administrasi. Jakarta: PT Bumi Aksara

Siagian, S.P. (2012). Fungsi-Fungsi Manajerial. Jakarta: PT Bumi Aksara

Sukayat, T. (2016). Manajemen Haji, Umrah, dan Wisata Agama. Bandung: Simboisa Rekatama Media

Terry, G.R. (1986). Alih bahasa Winardi. Prinsip-Prinsip Manajemen. Jakarta: PT Bumi Aksara 
Novita Irawati \& Asep Iwan Setiawan

Terry, G.R., \& W, Leslie. (2014). Alih bahasa Ticoalu, G.A. Dasar-Dasar Manajemen. Jakarta: PT Bumi Aksara 